\title{
Brinde, de Maritta Lintunen
}

Pasi Loman ${ }^{1}$

Maritta Lintunen vem do leste da Finlândia, da cidade de Savonlinna, mas mora atualmente na capital do país, Helsinque. Desde sua estreia em 1999 até hoje ela publicou duas coleções de poemas, quatro coleções de contos e quatro romances. Lintunen considera-se uma escritora que escreve em três idiomas distintos nos três gêneros diferentes. E ela é realmente uma mestre do finlandês, fazendo dos seus textos uma leitura muito prazerosa. Por formação Lintunen é mestre em música, fato que talvez possa ser notado no estilo rítmico da sua escrita. Suas obras foram finalistas de vários prêmios literários, e notavelmente ela ganhou o prestigioso Prêmio da Fundação de Literatura de WSOY em 2010, que é dado como reconhecimento para a obra inteira da carreira de um escritor ou escritora.

Vários contos e poemas de Lintunen já foram traduzidos e publicados em mais de dez idiomas, inclusive em alemão, holandês, sueco e russo, em antologias e revistas de literatura. Em inglês, o seu aclamado conto Passiontide foi escolhido para a coleção "Melhor Ficção da Europa 2012" (Best Fiction From Europe 2012 Dalkey Archive Press) e o seu conto The Message Bearer foi publicado na revista Words Without Borders em 2014; ambos os contos são da coleção Ovisilmä (2006).

As personagens em muitos dos contos de Maritta Lintunen são pessoas totalmente comuns, mas que se encontram diante de coincidências estranhas. $\mathrm{O}$ que eleva Lintunen acima de muitos outros escritores contemporâneos finlandeses

1 A tradução foi feita diretamente do original finlandês por Pasi Loman, finlandês radicado no Brasil desde 2006, e revisada por sua esposa Lilia Loman, que possui doutorado em crítica e teoria literária pela University of Nottingham e pós-doutorado pela PUC-SP. Para realizar várias traduções literárias sem fim lucrativo em 2017, incluindo esta tradução, Pasi recebeu bolsas de duas fundações finlandesas, Otavan kirjasäätiö e WSOY:n kirjallisuussäätiö. 
é seu vasto vocabulário e a sua habilidade extraordinária de usar metáforas vívidas para colorir os seus contos. Cada frase é construída com cuidado, cada palavra é escolhida cuidadosamente. A história flui, mas o leitor nem precisa de chegar até o fim do conto para se divertir com a leitura. Vale a pena, porém, continuar até o fim, pois muitas vezes há uma surpresa no parágrafo ou na frase final, que vira o conto de cabeça para baixo. O rico uso de provérbios, metáforas e adjetivos raros faz o processo de tradução dos contos de Lintunen um desafio para os tradutores. A história dos contos é fácil recontar em qualquer idioma, mas manter o estilo exige um esforço grande.

O finlandês e o português são dois idiomas muito diferentes, em quase todos os aspectos. A língua finlandesa faz parte da família de línguas urálicas e assim, por exemplo, não tem preposições; em vez disso o finlandês usa um sistema de declinação que conta com um sistema bastante complexo de 15 casos. $O$ finlandês não tem gêneros, nem para o pronome em terceira pessoa singular, que permite escritores esconder o sexo dos seus personagens. Devido a essas e outras grandes diferenças entre o finlandês e o português, por vezes é bastante difícil manter o estilo do texto original. Muitos escritores finlandeses, por exemplo, gostam de escrever frases muito compridas - principalmente em romances, não tanto em contos -; o sistema de declinações permite que seja fácil seguir o pensamento do autor e entender as frases muito longas, o que em português ficaria muito confuso. No caso de Maritta Lintunen, porém, o maior desafio é o vocabulário mesmo; até para uma dupla finlandês-brasileira, como os tradutores deste conto para a presente coleção de contos nórdicos. Em particular achamos difícil traduzir nomes de plantas e animais, pois muitas vezes não existe tradução exata para uma planta nativa da finlândia que não cresce em nenhum país lusófono; para uma obra de ficção seria estranho usar o nome da planta em latim; optamos então às vezes usar o nome da família da planta em vez do nome próprio da planta específica. 


\section{Kylkiäinen}

Maritta Lintunen

Auto keinahti kun isä pudottautui ähkäisten penkille ja käynnisti moottorin. Partanen kumartui ja tunki punakkaa naamaansa avonaisesta sivuikkunasta sisään. Nyhdin mekonhelmaa polvieni suojaksi. Miehen tihruisissa silmissä välähti.

- Kylkiäinen sovittu.

Isä tuijotti hetken eteensä ja varmisti:

- Kaksi tonnia?

- Sen verran siinä voitat.

Nytkähdimme liikkeelle. Kumara katajapensas raapaisi tutusti lokasuojaa. Minulta pääsi itku. Isän tuhahdus paljasti, että nyt olisi turha ruveta nyyhkimään. Valittamaan kuinka pohjattoman surullista oli ajaa viimeisen kerran tätä möykkelikköistä peltotietä. Kuinka raskasta oli hyvästellä harmaa nukkuma-aitta, ikivanha pihakuusi ja tuo männikön lomitse siilautuva vadelmanpunainen valo, joka iltaisin värjää metsäsaarekkeista huokuvan usvan.

Veljen kysymys paukahti kojelautaan kuin kivi.

- Paljollako myit mökin?

Isän ilme ei värähtänyt.

- Sain sen minkä pyysin.

Ohitimme Saikkolan punamultaisen maatalon. Vanha pystykorva tunnisti automme, juosta hölkytti häntä heiluen langassa kohti maantietä ja vosahti ikäväisenä peräämme. Harmaantunut Hupi. Sitäkään en enää rapsuttaisi kauppa-autoa odotellessani.

- Kyllä minä arvaan, että teille tämä on vaikea asia. Mutta odotan myös ymmärrystä. Ette ole enää potkuhousuiässä.

Pikkuveli ja minä tiesimme, että sovitteleva osuus päättyisi tähän. Ota tai jätä. Pyyhkäisin kiivain liikkein silmäni kuiviksi.

Nahkainen takapenkki nisahti kun veli vaihtoi asentoa.

- Mistä kylkiäisestä teillä oli puhe Partasen kanssa?

Isän kasvoille levisi ovelantyytyväinen hymy.

- Sain kauppahintaan parin tonnin verottoman siivun.

Vilkku naksutti, isä odotti lähestyvää pakettiautoa ja tarkentavaa kysymystä. Siihen veljen ylpeys ei antanut myöten. Käännyimme kaupunkiin johtavalle tielle, isä vilkaisi vielä taustapeilin kautta veljeä kuin varmistuakseen ettei kysymystä tosiaankaan tule.

- Sannin autokoulu alkaa heinäkuussa. 
Kiskaisin yllätyksissäni henkeä.

- Mitä?! Eihän meillä pitänyt olla varaa ajokorttiin.

- Nyt on.

Takapenkiltä kantautui äänenmurroksesta johtuva karautus.

- Et kysynyt haluaako Sanni käydä Esko Partasen autokoulua.

Kuvio valkeni nyt minullekin - ilonläikähdykseni kuoleutui hetkessä. Isän hampaiden raosta sihahti sylkipisarainen saatana.

-Kaupantekiäisenä kahden tonnin arvoinen ajo-opetus! Eikö tarjous kelpaa?

Isä painoi kaasua ja ohitti pakettiauton ohimosuonet pullottaen. Ehdimme ajaa yli tasoristeyksen ja ohi lakkautetun kyläkaupan ennen kuin veli jurahti:

- Kuka haluaa käydä autokoulunsa firmassa, jonka nimi on EsKortti?

Tuijotin tuulilasia mitään näkemättömin silmin. Kuka haluaisi ajo-oppilaaksi hilseen peittämälle miehelle, joka itkee avioerojaan paikallisessa kaljakuppilassa ja vuokraa kioskista saksalaisia pornoelokuvia?

Kerrostalon parkkipaikalla oli autiota. Kaikki olivat viettämässä perjantaita kesämökeillään. Kaikki paitsi me. Ruosteisella mattotelineellä roikkui yhä naapurin tummanpunainen persialaismatto, jolle koira oli oksentanut.

Isä sammutti moottorin ja jäi istumaan paikoilleen. Se merkitsi ettemme mekään liikahtaisi ennen kuin oli lupa.

- Sanni pääsee vielä elämässä pitkälle.

Tuulenpuuska tutisutti lipputankoa.

- Tiedättekö miksi?

Kuuntelimme äänettä isän yksinpuhelua. Veli vältti nisauttelemasta nahkapenkkiä. Koetin hengittää keuhkojen kärjillä, jotta pysyisin mahdollisimman olemattomana.

- Sanni osaa totella.

Haistoin veljestä värähtävän tuoksun - aavistus hikeä, multaisten lenkkareiden ja pitkässä heinikossa kostuneiden farkkujen lemua.

- Ota Jere oppia siskostasi ja pidä suusi kiinni.

Helteinen yö painoi vartaloa, viskasin peiton lattialle. Ovi raottui, Jeren sekainen hiuspehko vilahti hämärässä.

- Sanni. Missä sä olet luuhannut?

Naulitsin katseeni katossa roikkuvaan vaaleanpunaiseen riisipaperilamppuun. Lapsellinen prinsessaruusuvarjostin, jonka äiti osti minulle kun täytin kolmetoista. Veli odotti itsepintaisena vastausta.

- Lotan luona. 
Jere sulki oven takanaan ja istahti sängyn jalkopäähän.

- Valehtelet.

Nielaisin tyhjää.

- Olin rannassa.

Veli jäi kuulolle. Ääneni painui kuiskaukseksi.

- En haluaisi mennä enää ajotunneille.

Vilkaisimme vaistomaisesti ovelle - isän kuorsaus kantautui tasaisena seinän takaa.

- Partasen takia?

Pidättelin hengitystäni. Veli kouhaisi hiuksiaan hämmentyneenä ja alkoi hakea sopivia sanoja. Puistin päätäni.

- Älä kysy mitään.

Suljin silmäni, pallean päälle vierähti lohkare.

Kolmannella tunnilla se käskee ajaa moottoritielle - painan kaasua, mutta en tarpeeksi - ei saa jäädä tulpaksi liikenteeseen - turpea kämmen ujuttuu polvelleni, tottelen ja mittari kohoaa sataankymmeneen, silti kämmen painaa yhä - byvä tyttö, ajetaanpa tuttua reittiä, rampista oikealle - peukalo hieraisee lumpiotani, kainaloni kostuvat - ja seuraavasta vasemmalle - yhtäkkiä minä tajuan matkanpään, käsi liukuu ylös reidelleni, sormenpäihini räjähtää tikkuileva tunne - nyt viittäkymppiä, peltotietä biljakseen, eipä ole kukaan niittänyt väylää anki - miehen ääni on käheytynyt, koura hohkaa kuumuutta, hamuaa jalkoväliäni, allamme kohisee pitkä, kiiltävä heinikko - ei saa, kirkaisen - pihakuusen kohdalla polkaisen jarrua, turvavyö puristaa, käsi työntyy puseroni sisälle, kaivaa rinnan esiin liivistä, miehen harmaantunut tukka haisee lialle, tarraan hikisistä poskista kiinni, painan kynteni syvälle lihaan - minun kylkiäiseni - mies vääntää kättäni katkeamispisteeseen ja avaa farkkujeni vetoketjun.

Jere haki tupakat ja sytytti minullekin oman. Sitten veli avasi ikkunan ja jäi retkottamaan ikkunalautaa vasten. Yösateesta kostean pihakoivikon tuoksu sekoittui tupakanhajuun. Jokin haikea, menneisiin kesiin liittyvä muisto raapaisi hellästi mieltä.

- Mitä se teki sinulle?

Vedin niin pitkän henkosen että minua alkoi huimata. Kun avasin silmäni, Prinsessa Ruususen mekonhelma valahti varjostimen pintaa pitkin.

- Vastaa.

Käännyin kyljelleni ja pyysin veljeä puhumaan jostakin muusta.

- Muusta? Mistä helvetin muusta?

- Elämästä.

Jossakin pyrähti lentoon pikkulintu. Koivunoksa huojui hetken tyhjyyttään.

- Olikohan se äiti?

Jere tuijotti minua epäuskoisena.

- Tuo lintuko?

- Niin. 
- Kirjosieppo se oli.

Kurkkua painoi paksu pala.

- Jere. Mitä sinä ajattelet nyt kun äiti on kuollut?

Veli kääntyi selin, painoi päänsä alas ja oli pitkän aikaa vaiti.

- Että meiltä puuttuu lohtu.

Kohotin päätäni tyynyltä.

- Lohtu?

Tupakka lennähti alas asfaltille. Veli kiskaisi ikkunan äkäisesti kiinni.

- Ei enää ketään, jolle voisi puhua niin kuin ihmiselle.

Puristin tyynyn mytyksi kainalooni.

- Kaikki on epätodellista. On väärin, että Lotalla ja muilla tytöillä on niiin huoleton elämä.

Veli riuhtaisi t-paidan yltään ja asettui peilin eteen.

- Älä mieti niitä kanoja. Mieti jotain älykästä.

- Kuten?

Veli ponnisti rintakehäänsä kaarelle.

- Jos kasvattaisi lihakset.

Vetäisin savua henkeeni ja aloin yskiä.

- Tä? Mitä nauramista siinä on?

- En minä naura, vakuutin vesissäsilmin.

Veli räjäytti finnin olkapäästään ja käännähti äkisti kohti.

- Maailma on täynnä tuommoisia vittupääeskopartasia. Niistä ei pääse voitolle muutoin kuin taistelemalla.

Tumppasin tupakan tyhjään puuterirasiaan.

- Usko jo. Ei puhuta Partasesta.

Jere heittäytyi lattialle ja alkoi punnertaa. Kolmenkymmenen kohdalla tuli tauko. Poika kierähti punakkana selälleen ja huoahti synkkänä:

- Koeta aikuistua. Minä en voi ruveta sinulle äidiksi.

Nyrkki jysähti lattiaan vaativasti.

- Kuuletko? Tajuatko?

Nyökkäsin hätääntyneenä ja pinnistelin kuullakseni jatkuisiko isän kuorsaus. Veli aloitti uuden punnerrussarjan. Sanat putoilivat tiukkoina ja harkittuina äidin kutomalle räsymatolle.

- Elämä on selviytymiskoe. Siihen pitää valmistautua. 
Kello oli kahdeksan aamulla ja EsKortin piha autio. En ehtinyt vääntää avainta virtalukossa, kun takaovi tempaistiin auki. Penkille jysähti urheilukassi, sen jatkona veli. Partanen räpläsi turvavyönsä irti ja kääntyi katsomaan taakseen.

- Tämä ei ole taksi. Ole hyvä ja poistu.

Taustapeilistä heijastuivat kalpeat, kapeat pojankasvot.

- Sanni. Sä muistat reitin.

Käynnistin moottorin ja aloin peruuttaa. Partanen painoi opetusjarrun pohjaan.

- Ulos autosta!

Putkikassin vetoketju sirahti auki. Partasen otsalle läimähti kämmen, hilseinen takaraivo jäsähti niskatukea vasten. Tartuin miehen turvavyöhön ja kalautin sen takaisin lukkoon. Partasen leuat jäivät puolittain auki kun ilmastointiteippi kiepsahti kahdesti pään ympäri. Miehen kallo oli nyt tiukasti penkissä kiinni.

Jere syöksähti ulos ja riuhtaisi etuoven auki. Partanen ynähteli ja koetti tunkea sormiaan teipin alle. Jere koppasi lattialta auton ikkunaharjan, puinen varsiosa painui poikittain miehen kurkulle.

- Kädet irti teipistä!

Vilkaisin veljeäni hämmästyneenä. Tunne oli luonnoton - kuin olisin yhtäkkiä nähnyt tulevaisuuteen ja katsellut aikuista Jere Saarista. Miestä, joka on jo kokenut paljon elämässään.

Havahduin kun ilmastointiteippirulla lennähti syliini. Kieputin Partasen ranteet yhteen. Veli kuopaisi maiharinsa taskusta puukon ja katkaisi teipin. Mies alkoi kakostella ja yökkiä heti kun harjanvarsi lakkasi painamasta kurkunpäätä. Seurasin syrjäsilmällä kuinka veli sitoi sätkivät nilkat liikkumattomaksi paketiksi.

- Liikkeelle.

Kaksi oven paukahdusta, painoin kaasua. Käteni vapisivat olkapäistä saakka. Takapenkiltä kuului sytkärin naksahdus, vedin tupakan rauhoittavaa lemua keuhkoihini.

- Ajetaan pikkuteitä, niitä samoja joita fillaroitiin muksuina. Muistat kyllä reitin.

Nyökkäsin itsekseni. Totta kai muistin. Kuinka monina kesäaamuina olimmekaan Jeren kanssa pakanneet voileivät ja limsapullot reppuihimme ja pyöräilleet kolmenkymmenen kilometrin taipaleen mökille. Omaan pikku maailmaamme, jonne äiti ja isä autoilivat illalla töiden päätteeksi.

Ihanaa, saunakin jo lämpiämässä. Kyllä meillä on sitten reippaat lapset!

Valoisa, iloinen äiti.

Meidän kesiemme hengetär.

Joka äkillisesti kuoli syksyllä. Ja vei mennessään isältä kaiken ilon.

Mökkipihaan päästyämme vilkaisin sivulleni. Esko Partasen silmät olivat ammollaan. Hikikarpaloita, katkenneiden verisuonten sinertäviä rihmoja, vaikeaa huohotusta. Käänsin kasvoni toisaalle ja avasin auton ikkunan. Peipposen riemukas laulu solisi koivunlatvasta 
nurmikolle. Ehkä lintu tunnisti meidät? Jospa se olikin se sama peipponen, jonka helinään heräsimme täällä aamuisin?

Jere nousi autosta ja lähti kävelemään kädet taskussa rantaa kohti. Juoksin perään, viittoilin autoa kohti ja huusin:

- Mitä me tuolle tehdään?

Veli seisoi laiturilla ja tuijotti auringossa kimaltelevaa aallokkoa.

- Ei mitään.

Vilkaisin epäröiden autolle päin. Ei kai sitten. Kerran veli niin sanoi. Jere tiesi aina mitä oli tehtävä ja mitä kannatti jättää tekemättä.

Vedin syvään henkeä. Elämä oli täällä; tuoksut, äänet ja värit. Meidän lapsuusmaisemamme. Vain vene oli väärä. Ja tuo sininen teräslapio portin pielessä.

Liikkumattomana seurasin kuinka Jere irrotti valkoisen lasikuituveneen laiturintolpasta, asetti jalkansa sen keulaa vasten ja työnsi minkä jaksoi. Aallokko käänsi hitaasti venettä, keinunta voimistui, vesi paukkui kiiltävää kylkeä vasten. Pian tuuli alkaisi työntää venettä kauemmas rannasta.

Jere katsahti olkansa yli.

- Vesille venosen mieli!

Palleastani töykähti kireä nauru. Minusta ei olisi ikinä tuohon. Jere oli ollut aina peloton, äidin mukaan veljellä oli mielipiteitä siitä asti kun se oppi puhumaan. Kun isä heittäytyi hankalaksi, käytin Jereä äänitorvena. Jos en itse rohjennut mennä isän eteen, astui veli esiin ja asettui maalitauluksi. David vastaan Goljat, huokaisi äiti monet kerrat kuunnellessaan Jeren ja isän välistä väittelyä.

Vilkaisin portinpieleen nojaavaa lapiota. Äiti oli tarkka siitä, että mökin piha pidettiin kauniina. Tämä on meidän pieni paratiisimme, ei romuvarasto, äiti muistutti, jos isä jätti työkaluja lojumaan nurmikolle. Otin arkaillen pari askelta, lopun matkan jo juoksin. Tartuin lapioon, sinkosin sen ilmaan - ojasta kantautui matala tumpsahdus. Vavahdin kiihtymyksestä.

Olin uskaltanut.

Käännyin hitaasti tulojäljilleni. Vältin katsomasta autossa hikoilevaa hahmoa. Tiesin hyvin, että mies näki tekoni.

Veli nousi portaat ylös ja kaivoi taskustaan mökin vara-avaimen. Siinä oli vieläkin avaimenperänä sininen kuminalle.

- Nappasin myyntipäivänä saunan kamanan päältä. Aioin tulla käymään täällä joskus. Tämä on aina meidän mökki, lukee kauppakirjassa mitä tahansa.

Astuimme tupaan, tuttu hämärä sulki meidät syliinsä.

- Tuli takkaan ja puita uuniin.

Oletko tosissasi, tirskahdin. Pudottauduin vanhaan narisevajousiseen laiskanlinnaan. Hölmistyneenä seurasin kuinka Jere latoi tottuneesti koivuklapit takkaan pieneksi kodaksi. Sytkärin napsahdus, tuli tarttui käpristyvään tuoheen. Nokisessa tiilitakassa tanssi punainen 
liekki. Selän takana väreili aamuaurinko. Vaaleat, äidin ompelemat pellavaverhot siilasivat auringonvalon pehmeäksi uduksi.

Käperryin tuolin suojiin. Meitä piirittivät niin monenlaiset valot. Monenlaiset varjot.

- Muistatko Jere saunaillat? Uitiin yömyöhään. Paistettiin makkaraa. Tai paahdettiin omenoita.

Veli tuijotti halkoa nuolevaa liekkiä ja nyökkäsi heikosti. Annoin katseen kiertää pitkin tupaa. Takkasavun nokeama seinäryijy, vihreät lapsuudenajan kerrossängyt makuualkovissa. Äidin pikkuinen kirjahylly ruokapöydän yläpuolella, kaikki rispaantuneiksi luetut kirjat siististi rivissä. Aivan kuin äiti olisi ne juuri siihen järjestänyt.

Ääneni värähti.

- Hyvä ettei Partanen ole ehtinyt muuttaa järjestystä.

Jere kohenteli tulta, vaikkei olisi tarvinnut.

- Tämmöisenä se pysyykin.

Oli viisaampaa olla utelematta - ehkä kaikki vain tapahtuisi omalla painollaan. Joskus oli parempi olla sekaantumatta asioihin, koskematta siihen mitä toivoi tulevaksi.

Tuli kohisi unettavasti. Nousin tuolista ja kurkistin ikkunasta pihamaalle. Erotin autosta Partasen tumman ja liikkumattoman hahmon. Jospa mies oli saanut kohtauksen? Ahdistunut, mennyt paniikkiin ja tukehtunut?

- Älä hyppää siellä kyttäämässä. Ota mieluummin kaapista lihapyörykkätölkki ja lämmitä ruoka kattilassa. Tässä alkaa olla jo nälkä.

Tuvassa oli hiljaista. Niin hiljaista, että havahduin hereille. Takan nielu ammotti mustana. Hiillos oli kuollut sammuksiin. Kuu virui kalpeana läikkänä alkovin vaalealla lampaankarvamatolla.

Viltti valahti polviltani lattialle. Olin nukahtanut nojatuoliin, retkottanut useamman tunnin epämukavassa asennossa. Nyt tiesin mitä isä tarkoitti sanomalla että niskojen paikalla oli ratakisko. Käänsin päätäni ja inahdin kivusta.

Hiivin ikkunan ääreen. Kesäyö oli sakeanhämärä, vain järven sileä peili kuvasteli valoa. Uninen katseeni osui kahteen hahmoon. Toinen seisoi laiturilla selin, toinen kyyhötti polviasennossa kasvot järvelle päin.

Avasin tuvan oven äänettömästi. Jere oli opettanut minulle kuinka vingahtavaa ovea tuli käsitellä, jotta pääsi ulos muiden kuulematta. Astuin kuistille ja jäin pylvään taakse piiloon.

Puhe kantautui tyynessä yössä selkeänä.

Mä menen takaisin nukkumaan. Mutta sinä mietit sïnä asiaa aamuun asti. Veteen on turha yrittää kieriä, painut pohjaan nïn kuin märkä tukki. Onko selvä?

Jere tönäisee kengällään Partasta takamuksiin. Partanen uikahtaa teipin läpi. 
Sillä sekunnilla kun pubut muuta kuin käskin, isä tulee tietämään mitä teit Sannille. Sillä sekunnilla kun menet kertomaan jollekin tästä mökkeireissusta, isä ja minä kävellään lähimmälle poliisiasemalle.

Vastarannalla äännähtää kuovi. Veli kiertää Partasen eteen ja kiskaisee päätä ympäröivän teipin irti. Tuskaisa volahdus. Kylmänväristys putoaa hartioilta nilkkoihin asti.

Toista mitä sinun on tehtävä. Toista joka sana!

Jeren käsi nousee, käännän pääni toisaalle. Kuulen kuinka Jeren nyrkki rusahtaa Partasen poskeen. Mies kakostelee sylkeä laiturille ja alkaa sitten nyyhkyttää ja nyökkiä.

Menen isäsi luo ja perun kaupan. Kaikeki koituvat kulut tulevat minulle maksettavaksi. Isäsi saa perumisen johdosta byvän summan. Maksan sen pimeästi. Samalla maksan Sannille ajokortin Törnroosin autokouluun.

Viimeisen asian Partanen lupaa itkuun sortuen. Jere koppaa laiturilta teippirullan ja kiepauttaa miehen suun kiinni. Puukonterä välähtää, veli pitää sitä Partasen silmien edessä.

Minä, Sanni ja isä buolebditaan sïtä että joudut linnaan, jos lipeät yhdestäkin lupauksesta.

Puukko heilahtaa ja teippi katkeaa.

Sä et ole muuta kuin vittupääeskopartanen, joka käyttää heikompia hyväkseen!

Partanen jää polvilleen laiturille. Miehen hartiat nytkähtelevät ennen kuin hän kaatuu kyljelleen. Sitten tulee hiljaista. Olin nukkuvinani kun veli avasi tuvan oven. Käsi laskeutui olkapäälleni.

- Keitän meille kahvit.

Teeskentelin haukotusta ja kysyin mitä kello on.

- Puoli viisi. Käytin Partasta kusella.

Jeren kädet tärisivät kun se kauhoi vettä kahvipannuun.

- Mitäs Partanen?

- Juteltiin niitä näitä.

Näyttelin hämmästynyttä.

- Irrotit teipin?

- Suu kiinni on helvetin vaikea puhua.

Kaasu kohisi, liekki leimahti, vapiseva käsi siirsi pannun lieden päälle. Veljen oikeassa rystysessä punersi veri.

- Juodaan kahvit ja palautetaan auto ja ukko EsKortin pihaan.

Jere katsoi minua kysyvänä kuin odottaen hyväksyntää ehdotukselle. Kaivoin korppupussin ruokakomerosta ja valitsin sokerisimmat lautaselle.

- Mitä sen jälkeen tapahtuu?

Jere nuuhkaisi kahvijauhoa ja hymähti.

- Mitäkö? Otetaan fillarit, käydään rapsuttamassa Saikkolan Hupia. Tullaan tänne.

Tuijotin veljeä epäuskoisena.

- Sanni. Lopeta teeskentely. Luuletko etten huomannut kun kurkit pylvään takana? 
Puraisin korppua, sokeria ripisi syliini. Ajatus tuntui uskomattomalta. Se, että kaikki kääntyisi entiselleen. Hengähdin syvään. Lapsuudesta oli pidettävä kiinni. Meiltä oli viety jo äiti.

- Jere. Pidettäisiinkö ennen koulun alkua täällä pikkuruiset bileet?

Veli nappasi korpun kädestäni ja rouskaisi siitä palan.

- Ei. Me pidetään ihan hitonmoiset bileet.

Minua alkoi hihityttää, sitten hihitys paisui hysteeriseksi kikatukseksi. Nauroin ensimmäistä kertaa äidin kuoleman jälkeen. Pyyhin silmiäni, vilkaisin järvelle ja näin laiturille lysähtäneen hahmon. Nauruni katkesi kuin leikaten.

Jos äiti tietäisi.

Tai ehkä hän tietääkin? Äiti kyllä hyväksyisi tekoni.

- Mitä mietit?

Sävähdin kysymystä - Jere oli viimeinen, jolle kertoisin totuuden. Juuri veljen vihan ansiosta elämämme korjautuisi.

- Mietin kuinka hyvin asiat voivat kääntyä. Yhden päivän aikana.

Jeren huulet liikahtelivat kun se mittasi äänettömästi kahvilusikallisia. Käännyin selin ja seurasin kuinka nouseva aurinko tavoitteli yöstä kosteita laiturintolppia. Partasen lasikuituveneestä ei näkynyt merkkiäkään. Se oli varmasti ajelehtinut niemen toiselle puolen.

Painoin nenänpääni viileään ikkunaruutuun.

Olin lukenut iltaisin Lotalta lainaamiani naistenlehtiä. Niissä käskettiin tyttöjä pitämään kiinni oikeuksistaan. Jokaiselle kuului koskemattomuus. Jokaisesta koskemattomuuteen liittyvästä loukkauksesta tuli ilmoittaa viranomaiselle.

Partanen oli koskettanut sormellaan häpyäni. Se varmasti vastaisi raiskausta. Mies oli pyytänyt anteeksi ja luvannut, ettei enää ikinä tekisi sellaista. Kuinka säälittävä yritys painaa väkivallanteko villaisella. Jo senkin vuoksi minulla oli oikeus kutsua tekoa raiskaukseksi.

Ensin Jere oli tulla hulluksi vihasta. Sitten veli vetäytyi omiin oloihinsa ja punoi suunnitelman.

Kaikki tulevat luottamaan sanaani. Kuka uskoisi hikoilevaa ja tihrusilmäistä Partasta, jonka toimiston vessassa on juliste lateksipukuisesta pornomallista? Kaikkien mielestä olisi oikeus ja kohtuus, että minä ja Jere saisimme takaisin sen minkä Partanen meiltä vei.

Kaikkien mielestä minun kertomukseni on paras. 


\section{Brinde}

Maritta Lintunen

Tradução do finlandês:

Pasi Loman

O carro balançou quando meu pai entrou, grunhindo, e deu partida. Partanen se inclinou na janela e pôs a cabeça para dentro do carro. Puxei o vestido para cobrir meus joelhos. Os olhos do homem brilharam.

- Combinado, concordo com o brinde.

Meu pai olhou para longe por um instante e confirmou:

- Dois mil?

- Isso é o que você economiza.

O carro pôs-se a andar. O zimbro riscou o para-lama, como sempre. Comecei a chorar. O jeito como meu pai resmungou mostrava que não era para choramingar naquela hora, para reclamar como era triste passar por aquela estrada rural pela última vez. Como era difícil dizer adeus para a cabana, o velho abeto e aquela luz vermelha que vem de trás das árvores e que, à noite, pinta a neblina na beira da floresta.

A pergunta do irmão foi como uma pedra jogada contra o carro.

- Vendeu a cabana por quanto?

A expressão do pai não mudou nem um pouco.

- Recebi o que pedi.

Passamos a casa vermelha de Saikkola. O velho cachorro reconheceu o nosso carro, correu em direção à estrada abanando o rabo e começou a chorar quando passamos e a guia o deteve. Hupi, já com pelos cinzas. Não vou mais poder afagá-lo enquanto espero a van do mercadinho chegar.

- Imagino que isso seja um assunto difícil para vocês. Mas espero que entendam. Você não são mais bebês.

Eu e meu irmão mais novo soubemos que a paciência do nosso pai tinha acabado. Era pegar ou largar. Com movimentos rápidos eu enxuguei minhas lágrimas.

O banco de trás de couro fez um barulho quando meu irmão se mexeu.

- De qual brinde você estava falando com Partanen?

Um sorriso maroto apareceu no rosto do pai.

- Consegui negociar que uma parte do preço, dois mil, fosse sem impostos. 
Com o sinal piscando, meu pai esperou a passagem de uma van e a pergunta seguinte. O irmão era orgulhoso demais para isso. Viramos na rua em direção à cidade. Meu pai olhou no retrovisor como que para verificar que a pergunta realmente não seria feita.

- A autoescola de Sanni começará em julho.

Respirei fundo de surpresa.

- O quê?! Você disse que não tínhamos dinheiro para a carta de motorista!

- Agora temos.

Meu irmão, com a mudança de voz, fez um barulho estranho no assento traseiro.

- Você nem perguntou se Sanni quer ir à escola de Esko Partanen.

Nesse instante o esquema ficou claro para mim também - minha felicidade morreu naquele instante. Nosso pai praguejou tanto que chegou a cuspir.

- A autoescola custa dois mil com um brinde! A oferta não lhe agrada?

Meu pai começou a dirigir mais rápido e ultrapassou uma van com o rosto todo vermelho. Tivemos tempo de atravessar a ferrovia e a loja fechada da aldeia antes de meu irmão falar com raiva:

- Quem quer estudar numa autoescola chamada EsCarta?

Olhei para frente sem ver nada. Quem gostaria de ser aluna de um homem cheio de caspa, que fica chorando por conta do seu divórcio no barzinho e aluga filmes pornô alemães do quiosque?

O estacionamento em frente ao prédio estava vazio. Todo mundo tinha saído para passar o fim de semana na cabana de campo. Todo mundo exceto nós. O tapete persa do nosso vizinho, em que o cachorro dele tinha vomitado, continuava estendido lá fora, numa varanda enferrujada.

Meu pai desligou o carro e ficou sentado. Isso significava que nós não poderíamos nos mexer enquanto não recebêssemos permissão.

- Sanni ainda vai longe.

O mastro da bandeira sacudiu ao vento.

- Sabem por quê?

Escutamos o monólogo de meu pai em silêncio. Meu irmão evitou se mexer para não fazer barulho no banco de couro. Tentei respirar levemente para existir o menos possível.

- Sanni sabe obedecer.

Eu podia sentir o cheiro de meu irmão - um pouco de suor, tênis enlameados e calça jeans molhadas por andar na grama comprida.

- Jere, aprenda com a sua irmã e fique calado.

A noite estava quente e abafada e eu joguei o cobertor no chão. A porta se abriu e vi o cabelo descuidado de Jere na escuridão. 
- Sanni. Onde você estava?

Fixei os meus olhos no lustre cor-de-rosa no teto. Um lustre infantil de Bela Adormecida que minha mãe comprou para mim quando tinha treze anos. Meu irmão insistiu em uma resposta.

- Na casa de Lotta.

Jere entrou, fechou a porta e sentou-se na cama.

- Você está mentindo.

Engoli em seco.

- Eu estava na praia.

Meu irmão ficou escutando. Minha voz transformou-se em um suspiro.

- Eu não quero mais ir às aulas de habilitação.

Olhamos instintivamente na direção da porta - dava para ouvir o ronco do pai do outro lado da parede.

- Por causa de Partanen?

Prendi a respiração. Confuso, meu irmão mexeu no cabelo e procurou as palavras certas para falar. Eu balancei a cabeça.

- Não pergunte nada.

Fechei os olhos e senti um peso enorme como uma rocha em minha barriga.

$\mathrm{Na}$ terceira aula ele me põe a dirigir para a rodovia - eu acelero, mas não o suficiente - você não pode atrapalhar o trânsito - uma mão carnuda aperta o meu joelho, eu obedeço e o velocímetro mostra cento e dez, e mesmo assim a mão continua a pressionar - boa menina, agora vamos dirigir por uma rota mais familiar, vire à direita na rampa - o polegar roça meu joelho, meus sovacos ficam molhados - e na próxima à esquerda - de repente entendo aonde estamos indo, a mão desliza para o alto da minha coxa, as pontas dos meus dedos de repente formigam - agora cinquenta por hora, devagar na rua de terra, ninguém cortou a grama - a voz do homem fica rouca, a mão está quente e procurando a minha virilha, dá para escutar a grama comprida embaixo do carro, a grama brilhante - não pode, eu grito - quando chegamos a um pinheiro eu chuto o freio, o cinto de segurança aperta, uma mão surge por baixo da minha blusa e tira o meu seio da sutiã, o cabelo grisalho do homem fede, eu agarro aquelas bochechas suadas e aperto as minhas unhas com força - meu brinde - o homem gira a minha mão até quase quebrá-la e abre o zíper da minha calça jeans.

Jere foi pegar cigarros e acendeu um para mim também. Depois meu irmão abriu a janela e ficou fumando escorado contra o parapeito. $\mathrm{O}$ aroma das árvores molhadas na noite chuvosa misturava-se com o cheiro do cigarro. Uma lembrança fraca tocou gentilmente os meus pensamentos.

- O que ele fez com você?

Traguei tão fundo que fiquei tonta. Quando abri os olhos, vi o vestido da Bela Adormecida caindo no lustre.

- Responda. 
Virei de lado e pedi para meu irmão falar sobre alguma outra coisa.

- Outra coisa? Que porra de outra coisa?

- A vida.

Um passarinho voou. Um galho de bétula, agora vazio, sacudiu por um momento.

- Será que era a mãe?

Jere olhou com suspeita.

- Aquele pássaro?

- É.

- Era um papa-moscas preto.

Senti dor na garganta.

- Jere. O que você pensa agora que a nossa mãe está morta?

- Que nos falta consolo.

Levantei a minha cabeça do travesseiro.

- Consolo?

O cigarro foi jogado no chão. Meu irmão fechou a janela com raiva.

- Não há mais ninguém com quem falar como um ser humano.

Apertei o travesseiro contra o meu sovaco.

- Tudo é irreal. É errado que Lotta e as outras meninas tenham vidas tão sossegadas, despreocupadas.

Meu irmão tirou a camiseta e parou em frente ao espelho.

- Não pense naquelas garotas burras. Pense em algo inteligente.

- Como o quê?

Meu irmão abriu os braços e inflou o peito.

- Que tal aumentar os músculos?

Engoli fumaça e comecei a tossir.

- O que foi? O que há de engraçado nisso?

- Não estou rindo - assegurei com os olhos molhados.

Meu irmão espremeu uma espinha no ombro e virou para mim de repente.

- O mundo está cheio desses Esko Partanens malditos. Não há como vencê-los sem lutar contra eles.

Apaguei o cigarro em uma caixa vazia de pó.

- Pode acreditar. Mas não vamos falar sobre Partanen.

Jere se jogou no chão e começou a fazer flexões. Depois de trinta, fez uma pausa. O garoto virou, deitou de costas com o rosto todo vermelho e deu um suspiro. Ele ganhou um ar soturno e disse:

- Tente agir como adulta. Eu não posso assumir o papel de sua mãe.

O punho fechado bateu no chão, exigindo. 
- Você está escutando? Você entende?

Nervosa, mexi a cabeça e tentei escutar se o pai continuava a roncar. Meu irmão começou uma nova série de flexões. As palavras caíam, diretas e bem pensadas, no tapete feito à mão pela nossa mãe.

- A vida é um teste de sobrevivência. Temos que estar preparados.

Eram oito da manhã e estava deserto em frente à EsCarta. Eu nem tive tempo de virar a chave para ligar o carro quando a porta traseira se abriu. Uma sacola esportiva foi jogada no banco e depois meu irmão se sentou. Partanen abriu o seu cinto de segurança e virou-se para olhar para trás.

- Este não é um táxi. Por favor, saia.

Um rosto magro e pálido apareceu no retrovisor.

- Sanni, você lembra o caminho?

Eu liguei o carro e comecei a dar ré. Partanen brecou com o freio de instrutor.

- Saia do carro!

O zíper da sacola se abriu. Uma mão bateu na testa de Partanen e a cabeça com caspa foi puxada contra o banco da frente. Peguei o cinto de segurança do homem e afivelei-o novamente. A mandíbula de Partanen ficou parcialmente aberta quando a fita adesiva foi amarrada duas vezes por volta de sua cabeça. O crânio do homem estava agora firmemente preso ao banco.

Jere saiu rapidamente do carro e abriu a porta da frente. Partanen estava ganindo e tentou enfiar os dedos por baixo da fita. Jere pegou uma escova do chão do carro, e essa escova vermelha foi posta na garganta do homem.

- Não mexa na fita.

Olhei para meu irmão, surpresa. A sensação foi estranha - foi como se eu, de repente, estivesse vendo o futuro e vendo Jere Saarinen adulto. Um homem que já tinha muitas experiências na vida.

Acordei quando a fita caiu no meu colo. Amarrei os pulsos de Partanen. Meu irmão pegou uma faca do seu bolso e cortou a fita. O homem começou a sentir-se mal por causa da escova na garganta. Observei meu irmão fazer dos tornozelos agitados um pacote imóvel.

- Vamos.

As duas portas se fecharam e eu comecei a dirigir. As minhas mãos tremiam desde os ombros. Escutei um isqueiro no banco de trás e traguei a fumaça tranquilizante do cigarro.

- Vamos dirigir pelas ruazinhas onde andávamos de bicicleta quando crianças. Você lembra o caminho com certeza. 
Fiz um sinal afirmativo com a cabeça para mim mesma. Claro que me lembrava. Foram muitas as manhãs de verão em que eu e Jere colocamos sanduíches e garrafas de refrigerante em nossas mochilas e andamos os trinta quilômetros até a nossa cabana. Para o nosso próprio mundo pequeno, aonde nossa mãe e pai dirigiam à noite depois do trabalho.

Que maravilhoso, até a sauna já está esquentando. Como temos crianças boas!

Minha mãe, sempre radiante, feliz.

A fada de nossos verões.

Que de repente morreu no outono. E com isso acabou com a felicidade de nosso pai.

Quando chegamos à cabana eu olhei para o meu lado. Os olhos de Esko Partanen estavam arregalados. Suor, linhas azuis de veias rompidas, respiração arquejante. Virei meu rosto e abri a janela do carro. Os pássaros cantavam na árvore. Talvez o pássaro houvesse nos reconhecido? Quem sabe era o mesmo papa-moscas preto que nos acordava pela manhã?

Jere se levantou do carro e começou a andar em direção à praia com as mãos nos bolsos. Corri atrás dele, gesticulando para o carro e gritei:

- O que vamos fazer com ele?

Meu irmão parou no cais e olhou fixamente para as ondas brilhando ao sol.

- Nada.

Olhei desconfiada para o carro. Nada, então. Já que meu irmão disse... Jere sempre sabia o que tinha que ser feito e o que era melhor não fazer.

Respirei fundo. A vida estava aqui; os cheiros, os sons e as cores. A paisagem da nossa infância. Apenas o barco estava errado. E aquela pá ao lado da portão.

Sem me mexer, observei como Jere soltou o barco branco de fibra de vidro do atracadouro, apoiou o pé contra o casco e o empurrou-o com toda a força. As ondas viraram o barco lentamente, ele começou sacudir mais, a água bateu contra as laterais. Em breve, o vento começaria a empurrar o barco mais longe da praia.

Jere olhou para trás.

- O barco quer navegar.

Eu ri. Eu nunca seria capaz disso. Jere nunca tinha medo, e segundo a minha mãe meu irmão tinha opiniões desde que aprendeu a falar. Quando nosso pai se tornou difícil, usei Jere como porta-voz. Caso eu não tivesse coragem de ficar em frente do pai, meu irmão assumia o meu lugar e tornava-se o alvo. Davi contra Golias, a mãe sussurrou muitas vezes quando escutava Jere e nosso pai discutindo.

Olhei para a pá ao lado da portão. Minha mãe era sempre rígida quanto ao quintal da cabana, que devia ser mantido bonito. Este é o nosso paraíso, não um depósito de junco, minha mãe dizia caso meu pai deixasse ferramentas na grama. Dei uns passos à frente e pelo restante do caminho eu corri. Peguei a pá e a joguei para cima - um barulho abafado pôde ser ouvido de uma vala. Estremeci de emoção.

Eu tinha coragem. 
Virei-me lentamente para o lugar de onde eu viera. Evitei olhar para o homem suando no carro. Eu sabia bem que o homem vira o que fiz.

Meu irmão subiu as escadas e tirou do bolso a chave reserva da cabana. O chaveiro ainda era o ursinho azul de borracha.

- Peguei a chave na sauna no dia de venda. Eu pretendia fazer umas visitas de vez em quando. Essa sempre vai ser a nossa cabana, não importa o que esteja escrito no registro.

Entramos na cabana e a escuridão familiar nos abraçou.

- Fogo na lareira e lenha no forno.

Você está falando sério?, eu perguntei e ri. Me acomodei numa velha poltrona de molas que rangeu quando me sentei. Olhei atordoada para Jere colocando lenha na lareira. Ele acendeu o fogo com um isqueiro, sem nenhuma dificuldade. Chamas vermelhas dançaram na lareira coberta de fuligem. $\mathrm{O}$ sol da manhã ondulava às minhas costas. Cortinas claras costuradas pela mãe transformavam a luz em névoa suave.

Me encolhi na segurança da poltrona. Tantas luzes nos circundavam. Tantas sombras.

- Jere, você se lembra das nossas sessões de sauna à noite? Nadávamos até muito tarde. Grelhávamos salsichas. Ou assávamos maçãs.

Meu irmão olhou fixamente para as chamas que devoravam a lenha e acenou lentamente a cabeça. Deixei meu olhar correr por todos os cantos da cabana. A tapeçaria coberta de fuligem da lareira, o beliche verde da infância. A pequena estante de minha mãe em cima da mesa de jantar, todos os livros velhos bem organizados. Foi como se minha mãe os tivesse organizado assim.

Minha voz tremeu.

- Que bom que Partanen não teve tempo de mudar a ordem dos livros.

Jere mexeu na lenha em chamas, mesmo não sendo necessário.

- E vai ficar assim mesmo.

Era melhor não perguntar nada - talvez tudo acontecesse sem forçar, automaticamente. Às vezes é melhor não se envolver nas coisas, não mexer com o que você deseja.

O fogo me deu sono. Eu me levantei da cadeira e olhei para fora. Vi a silhueta escura e imóvel de Partanen no carro. E se o cara tivesse sofrido um ataque cardíaco? Ficado nervoso, entrado em pânico e sufocado?

- Não fique olhando aí. Melhor seria você tirar uma lata de almôndegas do armário e esquentar comida. Estou começando a ficar com fome.

Estava silencioso na cabana. Tão silencioso que eu acordei. A lareira parecia um buraco vazio e negro. O fogo tinha morrido. A luz fraca da lua refletia-se no tapete de pele de carneiro. 
O cobertor caiu do meu joelho até o chão. Eu tinha adormecido na poltrona e dormi horas numa postura desconfortável. Naquele momento entendi o que o pai queria dizer quando falava que no lugar do pescoço tinha uma barra de aço. Virei a cabeça e gritei de dor.

Esgueirei-me até a janela. A noite de verão estava pouco escura, havia apenas o espelho liso do lago refletindo luz. O meu olhar sonolento encontrou duas pessoas. Uma estava de costas no atracadouro, e a outra agachada, olhando para o lago.

Abri a porta da cabana sem fazer nenhum som. Jere me ensinara como lidar com a porta barulhenta para sair sem que outros escutassem. Saí ao alpendre e fiquei escondida atrás de um pilar.

Consegui escutá-los facilmente enquanto conversavam na noite calma.

E vou voltar a dormir. Mas pense nisso até de manhã. Não adianta tentar rolar para a água, afundará como uma pedra. Está certo?

Jere chuta a bunda de Partanen. Partanen geme por trás da fita.

No momento em que você contar a alguém qualquer outra coisa além do que eu lhe falei, meu pai vai ficar sabendo o que você fez com Sanni. No momento em que você contar para alguém sobre esta viagem para a cabana, eu e meu pai vamos à delegacia de polícia mais próxima.

Escutei um maçarico-real na outra margem do lago. Meu irmão saiu de trás de Partanen, ficou diante dele e tirou violentamente a fita que estava por volta de sua cabeça. Um grito dolorido. Um arrepio desagradável correu dos meus ombros até os tornozelos.

Repita o que você precisa fazer. Repita cada palavra!

Jere levanta o punho fechado, eu desvio o olhar para não ver. Escuto como o punho de Jere bate no rosto de Partanen. O homem cospe no atracadouro e depois começa a chorar e a fazer um sinal afirmativo com a cabeça.

Vou procurar o seu pai e cancelar o negócio. Todas as despesas vão ser pagas por mim. Seu pai receberá um bom valor por isso. Vou pagar sem recibo. E ao mesmo tempo vou pagar para que Sanni frequente a autoescola de Törnroos.

Essa última coisa Partanen promete chorando. Jere pega o rolo de fita e fecha a boca do homem. A luz reflete na lâmina da faca quando Jere a coloca em frente aos olhos de Partanen.

Eu, Sanni e nosso pai prometemos que você vai para a cadeia se não mantiver todas essas promessas.

A faca se mexe e a fita é cortada.

Você não passa de um filho da puta que abusa das mais fracas!

Partanen fica de joelhos no cais. Os ombros do homem tremem antes de ele cair de lado. Depois tudo fica quieto.

Eu fingia dormir quando meu irmão abriu a porta da cabana. Uma mão tocou meu ombro.

- Vou fazer café para nós. 
Fingi bocejar e perguntei as horas.

- Cinco e meia. Ajudei Partanen a fazer xixi.

As mãos de Jere tremiam enquanto colocava água no bule.

- Como estava Partanen?

- A gente falou sobre isso e aquilo.

Fingi que fiquei surpresa.

- Você tirou a fita?

- Cale a boca, está difícil falar, porra.

Escutei o gás ligado, ele pegou fogo e com uma mão tremendo colocou o bule sobre o fogão. Os nós da mão direita dele estavam ensanguentados.

- Vamos tomar café e depois devolver o carro e o cara ao estacionamento da EsCarta.

Jere me olhou como se esperasse uma resposta afirmativa. Peguei o saco de biscoitos e escolhi os que tinham mais açúcar.

- E o que vai acontecer depois?

Jere cheirou o café e sorriu.

- O que vai acontecer? A gente vai pegar as bicicletas e fazer carinho no Hupi, o cachorro dos Saikkolas. E depois a gente volta para cá.

Olhei fixamente para meu irmão sem acreditar nele.

- Sanni. Pare de fingir. Você acha que eu não percebi você espiando atrás do pilar?

Mordi o biscoito e um pouco de açúcar caiu no meu colo. A ideia pareceu incrível. Tudo voltaria a ser como antes. Respirei fundo. É necessário prender-se à infância. A mãe já foi tirada de nós. escola?

- Jere. Que tal fazer uma festinha aqui antes das férias acabarem e voltarmos à

Meu irmão pegou o biscoito da minha mão e deu uma mordida.

- Festinha não. Vamos fazer uma puta de uma festa de arromba.

Comecei a rir e em seguida a gargalhar histericamente. Eu ri pela primeira vez desde a morte de minha mãe. Esfreguei os olhos, olhei na direção do lago e vi aquela pessoa no atracadouro. Aquilo cortou o meu riso.

Se a mãe soubesse.

Ou talvez ela saiba? A mãe aceitaria o que fiz.

- No que você está pensando?

Vacilei ao escutar a pergunta - Jere era o último para quem eu contaria a verdade. Era exatamente graças ao ódio de meu irmão que as nossas vidas seriam consertadas.

- Pensei como as coisas podem melhorar. Durante um único dia.

Os lábios do Jere se mexeram como se ele calculasse silenciosamente quanto café colocar. Virei de costas e observei a forma como o sol nascente pintava os pilares molhados 
do atracadouro. O barco de Partanen já não podia ser visto. Com certeza estava à deriva do outro lado da península.

Apertei o meu nariz contra a janela fria.

À noite eu tinha lido revistas femininas emprestadas de Lotta. As revistas ensinavam as meninas a exigirem seus direitos. Todo mundo tem o direito de não ser tocada. Cada violação ao direito de não ser tocada deve ser denunciada às autoridades.

Partanen tocou minhas partes íntimas com o dedo. Isso provavelmente é o mesmo que estupro. $\mathrm{O}$ homem pediu desculpas e prometeu que nunca mais faria algo assim. Que patética essa tentativa de ignorar a violência. Só por isso eu já tinha o direito de chamar o que aconteceu de estupro.

Primeiro, Jere ficou louco de raiva. Depois ficou sozinho, planejando.

Todo mundo vai acreditar em mim. Quem acreditaria no suado Partanen, que tinha o pôster de uma atriz pornô vestindo roupas de látex no banheiro do escritório? Todo mundo vai achar que seria justo se eu e Jere recebêssemos de volta tudo o que Partanen tirou de nós.

Todo mundo acharia que a minha história é a melhor. 